\title{
How Government Response to COVID-19 in Bangladesh? An Overview
}

\author{
ISHTIAQUE ARIF ${ }^{*}$, MOHAMMAD MAKSUDUL KARIM ${ }^{2}$, \\ MD. SIDDIKUR RAHMAN ${ }^{3}$ and ABU BAKAR ABDUL HAMID ${ }^{4}$
}

${ }_{1,4}$ Putra Business School, University Putra Malaysia.

${ }^{2,3}$ Department of Management Studies, Comilla University.

\begin{abstract}
In this $21^{\text {st }}$ century, in front of the whole world it was a very unlikely occurrence of a new pandemic named as Covid - 19. First China and after other countries it advanced its black claw on Bangladesh. Bangladesh's government was aware of the pandemic's predicament and took steps to protect the population, as well as the economy and numerous industrial sectors. Though the government of Bangladesh did its hardest to provide all forms of assistance to the country's economy, the government was unable to successfully control the pandemic due to the country's large population and people's irresponsibility. Due to the significant impact of Covid-19 during this epidemic, various economic and financial sectors were severely harmed, particularly the garment industry sector. Covid - 19 also has an impact on financial institutions such as banks and other financial institutions. Small businesses, start-ups, and other commercial concerns were also severely harmed. The impact of the epidemic on these industries has had a huge impact on all sectors. This research aims to give a comprehensive and useful overview of the observed and potential consequences in the near future. The study relied on secondary data. Information was gathered from numerous media sources, articles, newspapers, policy experts, and other publications in order to better comprehend it. The goal of this research is to describe Bangladesh's pandemic challenges and government response to the worldwide issue.
\end{abstract}

\section{Introduction}

Bangladesh is a natural and attractive middleincome country in Southeast Asia. Its economy is fast growing. In the last decade, there has been tremendous progress in every aspect of life. However, the COVID-19 pandemic has had a negative impact on every area of Bangladesh's economy. COVID-19 is the pandemic disease

CONTACT Ishtiaque Arif

\section{(c) (i)}

(C) 2021 The Author(s). Published by Enviro Research Publishers.

This is an Open Access article licensed under a Creative Commons license: Attribution 4.0 International (CC-BY).

Doi:http://dx.doi.org/10.12944/JBSFM.03.01-02.09 
declared by World Health Organization (WHO) on $11^{\text {th }}$ March 2020 which is potentially severe acute respiratory infection caused by a novel evolving severe acute respiratory syndrome corona virus2 (SARS-CoV-2) (Shahriar, M. S., et al., 2021). On August 18, 2021 totalcases found in Bangladesh $1,440,644$ where total recovery was $1,327,028$ along with 24,719 death against the total test of $8,521,828$, when this virus infections were discovered in over 220 countries and territories around the world. (Worldometer, 2021, August 18).

While Bangladesh was concerned about the spread of COVID-19, the government implemented a broad and stringent economic and financial control measures. The current global economy appears to be displaying a precariously balanced condition from the consequences of the pandemic's effect. Due to the lockdown, Bangladesh's GDP has shrunk by 6 percentage points in 2020 compared to 2019 (News, 2020, June 12). Barriers to combating Covid-19 included a lack of resources and medical facilities, as well as insufficient testing facilities, personal protective equipment (PPE), and other safety measures. Furthermore, the crisis was made more severe by public knowledge and attitude, social distance issues, price hikes, and natural calamities. The mutation rate of Coronavirus in Bangladesh was 12.6 percent, according to a study by the Bangladesh Council of Scientific and Industrial Research (BCSIR), while the global average is 7.23 percent (Report, 2020, Sep 6).

International factories (pre-assembled garments, in the case of Bangladesh) have felt the burden of the global financial crisis, particularly due to readymade garments and remittance.Because of this nation's economy is almost entirely dependent on the world (Amit, 2020). Moreover, the supply chains of the RMGs have affected the economy of Bangladesh due to the risk of cross-exposed and material price changes brought about by these shipments have rendered it vulnerable, with approximately $80 \%$ of exports dependent on this market.

Table 1: Reported Cases and Deaths by Country or Territory

\begin{tabular}{lcccccccc}
\hline Country & $\begin{array}{c}\text { Total } \\
\text { Cases }\end{array}$ & $\begin{array}{c}\text { New } \\
\text { Cases }\end{array}$ & $\begin{array}{c}\text { Total } \\
\text { Deaths }\end{array}$ & $\begin{array}{c}\text { New } \\
\text { Deaths }\end{array}$ & $\begin{array}{c}\text { Total } \\
\text { Recovered Recovered }\end{array}$ & $\begin{array}{c}\text { New } \\
\text { Tests }\end{array}$ & Total & Population \\
\hline India & $32,295,224$ & $+10,123$ & 432,834 & +282 & $31,492,285$ & $+13,880$ & $496,629,524$ & $1,395,272,151$ \\
Pakistan & $1,109,274$ & $+3,974$ & 24,639 & +66 & 996,426 & $+3,122$ & $17,007,656$ & $225,709,450$ \\
Bangladesh & $1,440,644$ & $+7,248$ & 24,719 & +172 & $1,327,028$ & $+12,112$ & $8,521,828$ & $166,535,695$ \\
Malaysia & $1,466,512$ & $+22,242$ & 13,302 & +225 & $1,198,726$ & $+19,680$ & $20,809,264$ & $32,832,377$ \\
Nepal & 739,907 & $+2,613$ & 10,396 & +42 & 689,173 & $+2,104$ & $3,791,069$ & $29,725,553$ \\
Myanmar & 360,291 & & 13,623 & & 279,488 & & $3,371,634$ & $54,820,494$ \\
Sri Lanka & 365,683 & & 6,434 & & 314,340 & & $4,575,585$ & $21,514,383$ \\
Afghanistan & 152,411 & +48 & 7,047 & +4 & 107,927 & & 747,196 & $39,912,306$ \\
Maldives & $\mathbf{7 9 , 4 1 9}$ & & $\mathbf{2 2 2 2}$ & & $\mathbf{7 7 , 5 0 6}$ & & $\mathbf{1 , 2 6 8 , 5 2 1}$ & $\mathbf{5 5 1 , 2 4 0}$ \\
Total: & $\mathbf{3 8 , 0 0 9 , 3 6 5}$ & $\mathbf{4 6 , 2 4 8}$ & $\mathbf{5 3 3 , 2 1 6}$ & $\mathbf{7 9 1}$ & $\mathbf{3 6 , 4 8 2 , 8 9 9}$ & $\mathbf{5 0 , 8 9 8}$ & $\mathbf{5 5 6 , 7 2 2 , 2 7 7}$ & $\mathbf{1 , 9 6 6 , 8 7 3 , 6 4 9}$
\end{tabular}

Sources: (Worldometer, 2021, August 18)

As a huge populated and world's densest country, Bangladesh Govt. try their level best to defend the mass population from Covid and for this, Govt. initiated some protective measuresas lockdown, travel bans and maintaining social distancing. In this aspect Govt. and the citizens along with the health experts try to open the avenue to offset the severity from Covid-19.

The pandemic situation was shown and observed negatively by various researchers, authors, intellectuals all around the world. WHO was also criticised by different nations for their activities against Covid-19. Bangladesh also faced the same type of criticism and the initiatives taken by the Govt. was not appreciated in a welcome manner. So, there is a gap which can be address in this study is to depict the Govt. contributions with minimum resources to face the challenges of Covid -19 in one of the most populous country. 
As the coronavirus outbreak spreads across the globe, many governments are implementing nontherapeutic preventive measures such as travel bans, remote office operations, country lockdowns, and, most crucially, social isolation. However, in Bangladesh, a lower-middle-income country with one of the world's densest populations, these efforts meet obstacles. In many parts of the country, social distance is difficult, and implementing mitigating measures with the country's limited resources would be extremely tough. On a local level, mobile sanitization facilities, temporary quarantine sites, and healthcare facilities could help limit the pandemic's impact. With prompt international aid and empathic engagement between the government, citizens, and health specialists, the country can reduce the pandemic's impact.

The goal of this research is to describe the pandemic's challenges and their socioeconomic consequences for Bangladesh's economy and the research question is:

What is the potential economic repercussions of the COVID-19 epidemic in Bangladesh, as well as the government's and other stakeholders' efforts to mitigate the impending economic shock?

\section{Research Method}

It is a qualitative study focused on Bangladesh based on secondary data. Because for understanding epidemic like Covid-19, qualitative methods can play a crucial role, the people involved in them, and effective solution and strategies (Teti et al., 2020). The secondary data were collected from review of literature like published journal articles, newspaper reports, and online publications. In addition, the authors collect data from new cases, total cases, the number of deaths and total recoveries, and the total population tested through WHO Database alongwith Worldometer Coronavirus Databases.

\section{Impact on Readymade Garments (RMG) \& Remittances}

The Outbreak of COVID-19 is the worst pandemic in the world for years (Onyema et al., 2020). According to The International Labour Organization (ILO) around 24.7 million jobs will be disappeared due to COVID-19 (McKeever, 2020). Like the other developed and developing countries, Bangladesh is also one of them who will be affected higher than anyone. Due to this epidemic, Bangladesh's apparel industry has been particularly affected, as the majority of the workers are women, who have no job security. Because practically the entire world is closed down, there is no change in revenue for garment brands and customers.

Because of the financial losses incurred by buyers and brands, the suppliers' orders are cancelled and six (6) billion orders have been postponed (Kamruzzaman \& Sakib, 2020, March 26). The workers in the Ready-made garments industry were affected by the order cancellation. Workers were not paid their legal wages. According to a survey, 72.4 percent of Bangladeshi manufacturers were unable to provide some form of income to their workers when they were furloughed. When order cancellations resulted in worker dismissals, 80.4 percent of Bangladeshi suppliers stated that they were unable to compensate the workers (Anner, 2020). The Managing Director of Denim Expert Limited, Mr. Mostafiz Uddin assumed that a few apparel workers might get job losses due to the COVID-19(Noyon, 2020, May 13). The Asian Development Bank (ADB) estimated that 894,930 workers in Bangladesh would lose their jobs as a result of the COVID-19(Perera, 2020). According to the Bangladesh Garment Manufacturers and Exporters Association (BGMEA), more than 70 factories were closed in the last year and 1,200 in the previous four years as a result of brand and buyer factory remediation initiatives following the Rana Plaza collapse, which resulted in the firing of more than 50,000 workers (Perera, 2020). So, the apparel workers are those who are the ultimate affected by any major incident in the apparel industry.

$H$ \& M, the country's greatest buyers of RMG, are cutting ties with their suppliers in Bangladesh, all of which means that they are shutting their factories and growing their costs by hundreds of millions of dollars. Major retailers $\mathrm{H}$ \& $M$, Zara, and $M$ \& $S$, and Primark have all decided to stay closed in the wake of the current supply shortage of Bangladeshi RMG garments. The global COVID-19 phenomenon affected both purchasing habits and the capacity for discretionary spending, bringing commerce to a complete halt. 


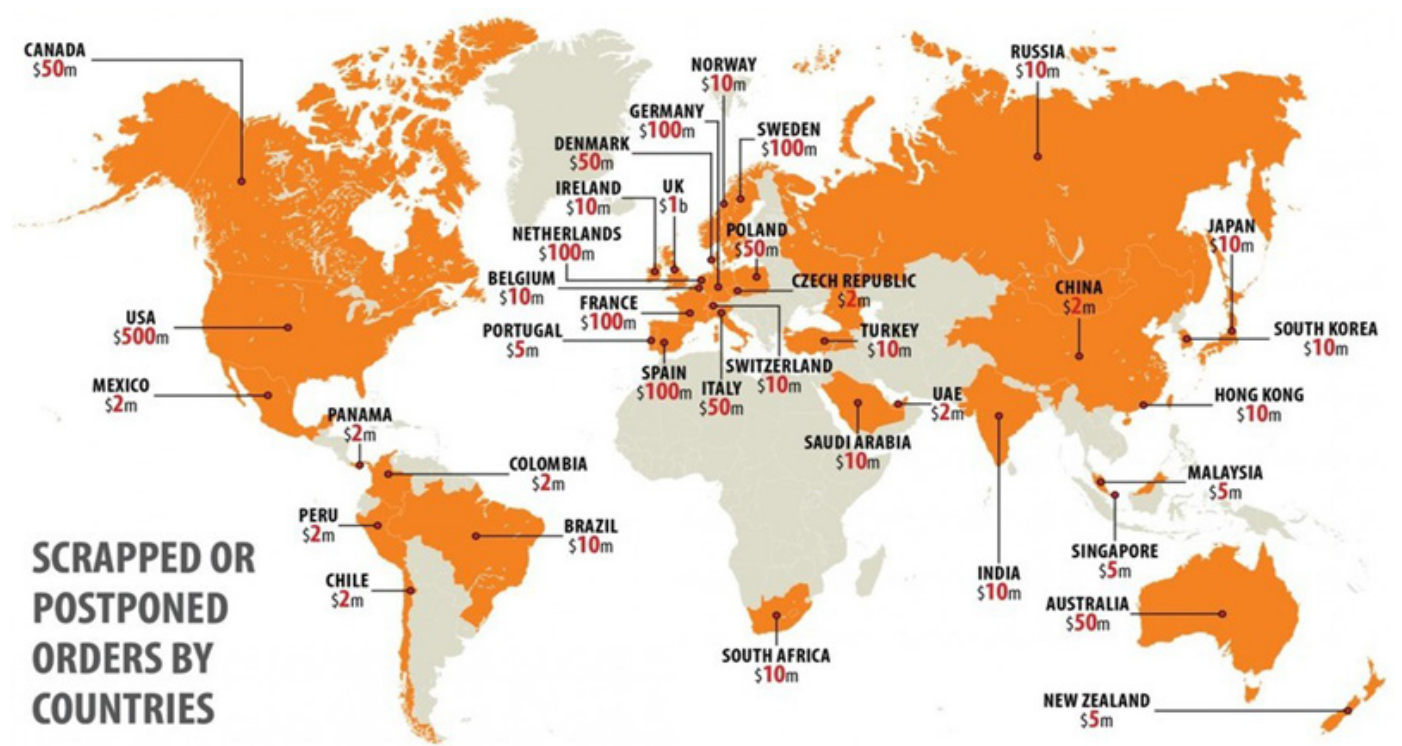

Fig. 1: Map of RMG Buyers Scrapping or Postponing Orders by Countries

Source: Preetha \& Islam (2020)

The recent explosion of the foreign companies have been undergoing has impacted its ability to purchase more Bangladeshi apparel, hence, and now $\mathrm{H} \& \mathrm{M}$ is having to "temporary stop" the expansion of orders and to review its current ones. perception, non-perception While it has committed to making payments to provide items before the global pandemic, $\mathrm{H}$ \& $\mathrm{M}$ is additionally involved in the delivery of various orders from abroad that have been anticipated before the outbreak(Mina et al., 2020; Rahman \& Ishty, 2020). According to data from the Bangladesh Textile Manufacturers and Exporters' (BGME), \$300 million worth of Primark orders a month equates to 2 million monthly wages for all the industry's garment staff. The disease impacts global production chains, buyer demand, of course, and furthermore, the wellbeing of employees, as well, and it is predicted to have lost about $\$ 4.2$ billion in export sales by the end of the fourth quarter if it persists at the current rate (Bain, 2020, March 21).

\section{Impact on Financial Sector}

At present, a large number of banks and other companies in Bangladesh are under the COVID net. Banks were coming to grip with the recent announcement the Ministry of Finance made that $6 \%$ on loans and $9 \%$ on deposit interest rates. The prediction should be taken into consideration, as the continued decline of private sector development after 2019 is not applicable anymore (Figure 2).
According to figures from the Bangladesh bank, it climbed by 16 base points in November, 2020 to 8.37 percent.Credit growth of the private sector in the central bank was $14.8 \%$ for the fiscal year of 2020 based on its previous anticipation. The prime lending rate decreased from $9.2 \%$ in January to $8.6 \%$ during the countrywide banking halt from March 26 to May 30,2020 . The surplus liquidity in the financial sector peaked at Tk 204.7 billion in December, the maximum in recent years (Hasan, 2021, Jan 25). To sum up, the above two trends, the increase in remittance inflow and the drop in imports led to the rise in banking liquidity (Hasan et al., 2017).

\section{Impact on Small Businesses and Start-ups}

The outbreak of Coronavirus has put almost every country in the world on lockdown, including Bangladesh. People are losing their jobs as economies slow down, and a large number of lowincome people are falling into extreme poverty. E-commerce businesses are also facing difficulties as a result of transportation restrictions and consumer concerns about being infected by delivery men. E-commerce sites were also unable to source products at first because all of the stores were abruptly closed. Fashion, IT services, cosmetics, dairy products, household stationery, cleaning supplies, sanitizers, and health products are just a few examples (Hasan, 2021, Jan 25). Although all of the products were eventually made available to 
e-commerce sites in certain circumstances, they continued to suffer as the majority of the delivery men failed to provide commodities on due time to customers. All of these challenges were only temporary, and as time passed, e-commerce site traffic began to rise (Hussain et al., 2021).

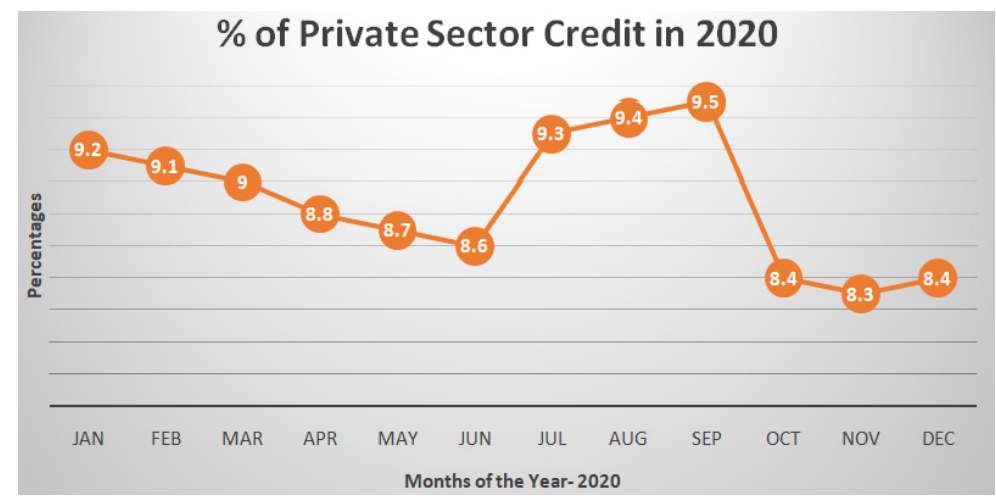

Fig. 2: Growth Rate of Private Sector CreditSource: Preetha \& Islam (2020)

Source: (Hasan, 2021, Jan 25)

Small and medium enterprises (SMEs) play a crucial role in ensuring economic development and achieving desired growth. The government is working hard to ensure that everyone has an equal opportunity to participate in the SME sector, which is characterized by low capital and short production cycles. The government is putting in place priority programs to develop small and medium-sized businesses, particularly among women, as well as industrial workers in rural and marginal areas.
The government has adopted several incentive packages for micro, cottage, and small and medium enterprises, including low-interest working capital facilities worth Tk.20,000 crore, the majority of which have already been implemented, to address the economic impact of the COVID-19 pandemic. Once the government's initiatives in the SME sector are fully implemented, it is expected that this sector's contribution to the national economy will rise to $32 \%$ by 2024 (Zahid, 2020, May 10).

Table 2: Impact of Small Business \& Start-ups

Sector Impact

Mobile

Payments

Ridesharing

Food \&

Grocery
The handling of cash is becoming more difficult for bKash. For the time being, this mechanism has been broken, they'll have to manually retrieve money from agents' deposit boxes and put back into their accounts. This is an important sector that needs additional monetary policy help in order to be able to limit the number of people who cashing out; on the other hand, retailers need to be persuaded to welcome digital money in order to limit expansion. The success of digital payments for the whole environment is of the financial services industry depends on it. It serves as the backbone for the bulk of the funding for the technology startup industry. It is like the skeleton of the whole process for potential success.

In line with the BRTA law, the app (Uber and Pathao) has been deactivated to restrict the circulation of the number of COVID-19. However, this is now a matter of controversy and it seems to be consistent with the moratorium on this. These measures would have both a market and supply-side effect on Pathao, Uber, and on Uber, they will create added demand. One path has offered is the new for the new company is the possibility to purchase medications and necessities as well as grocery and expansion facilities such as Pathao Par.

On average, the industry has seen a general decline in the number of food distribution companies. About that, the platforms are operational: The food delivery apps Food 
Vol. 03(1-2) 92-102 (2021)

Delivery $\quad$ Panda, Uber Eats, and Shoko Food have been added to the chart. Due to a spike in distribution of groceries in ChalDal, there was only a sharp demand at the time of ChalDal at the moment of publication. As a result, customers want to prepare their own meals in their own homes rather than in restaurants, however, most distribution companies have found out this to be troublesome. The most popular apps in the food delivery market now have "contactless" payment options that let customers pay for their orders with mobile wallets or credit cards.

E-Commerce Because of the rise in e-commerce websites, most E-commerce networks have taken and Home a significant hit. The vast majority of them have been placed under constraint from Services supply issues. The work ceased in Daraz and was closed for 10 days. A fast online ecommerce website for service providers, such as Sheba saw an increase in the amount of services performed for property such as deep cleaning. Furthermore, she has demonstrated a commendable commitment to community service by using a mission to produce and donate sanitizers in conjunction with Dhaka University's Chemistry Department of Textiles and Science.

E-Health There is a lot of promise in the Bangladesh's e-health ecosystem, but just a small number (Tonic) of start-upsthat can currently stand on their own without drawing on outside capital. Tonic, formerly operated by Telenor Health, has seen a $30 \%$ increase in phone consultations and is anticipated to make a live consultation video app debut in the near future And, in addition, they've also introduced a symptom checker in Bengali. The scope for development in this industry has been underlined by COVID-19.

Sources: (Amit, 2020)

Start-up companies in strong economies face all kinds of problems even in times of strong economic growth. When it comes to public equities, and even to the value of gold, the downturn will start around the coronavirus era. There is a silver lining to this situation: The government has unveiled a multisectoral stimulus package which is essential for the clothing businesses, banking system, both exporters and importers, impels people to action, supplies, and safeguards tourism, aviation, and hospitality.

Ultimately, Covid-19 would help to identify systemic problems with our health care system, flexibility in our workforce, outdated technology, our job environments, and our workforce, and public and business policy, as well as we've done so far. Perhaps the virus can make us more socially and (or first) protective as well as provide us with an additional protective capability. As a result, it will allow us to further down the digital transformation path. We are not looking to be deterred, but only to proceed in a spiralling pattern (Deb \& Nafi, 2020).

\section{Government Initiatives to Tackle Pandemic Challenges}

To combat the outbreak of pandemic COVID-19, almost every nation is employing vigorous non- therapeutic interventions. Bangladesh has gone down the same path as the rest of the world(Islam et al., 2020). The government of Bangladesh has taken many significant measures to fight COVID19, including 1) the creation of a national COVID-19 response committee led by the Minister of Health; and 2) the establishment of a national COVID-19 response committee led by the Minister of Health. 3) cancellation of the grand inauguration ceremony of Bangabandhu Sheikh Mujibur Rahman's birth centenary celebration programs; 4) closure of all government and private offices; 5 ) closure of all educational institutions in the country; 6) prohibition of all public gatherings and transportation services; 7 ) cancellation of the Bangla New Year celebration on April $14 ; 8$ ) cancellation of the $50^{\text {th }}$ Independence Day celebration event; 9 ) operation of the 'Rice for Tk. 10 per KG (approximately 12 cents $/ \mathrm{kg}$ rice)' initiative for vulnerable citizens around the country Furthermore, the civic society, philanthropists, and wealthier members of society are generously aiding the deprived class of society by providing nutritious and financial assistance (Kamol, 2020, Mar 09).

Among the several initiatives put forward by the government in an overall USD 11.90 billion package for business, small and medium enterprises, 
cottage industries, doctors, and the homeless have also got one. The funding is in place to help safeguard the country's food and nutritional security by means as well as homeless people with the medical establishment, nurse, and the agricultural healthcare component of USD 10 million (Desk, 2020, April 13). Though the corona virus had been identified afterfive months, treatment in Bangladesh was considered too dangerous and impractical because of the level of immobility and inability to coordinate their diagnosis and treatment (Bain, 2020, March 21). However, although there are shortcomings and issues with the overall health care system in Bangladesh, they are trying to improve it by increasing access and standardizing care that is good enough that a few people among the general population are now suffering from the consequences of a horrible health event like the coherence $19^{\text {th }}$ century pandemic, maybe because the scheme has fallen out of control the public health authorities were engaged in an extensive pandemic preparatory task to meet the COVID-19 pandemic campaign in the course of which they were preparing to handle any possible planning. The worst symptoms of this kind of an administration are obvious on the ground. Teamwork within the different government agencies is poor, and effective policies are often ignored or overridden by politicians and their staffs (Zahid, 2020, May 10). Furthermore, governments are unable to effectively control the people coming into the country since they are prohibited by the Government from travelling from the CON-19 nations (Anwar et al., 2020). Although identifying those infected with COVID-19 was a must, departments were plagued with confusion in the government of Bangladesh, other important actions had to be taken to address the issue, such as airports must organize themselves and adopt steps to discover whether any other passengers had it. To address the major challenges in Dhaka and Sylhet, however four more outbound departures were made via the Bangladesh's border crossings with other countries were outfitted with scanners and one in Chottogram while another five were obtained through Bangladesh's border crossings with other countries' outlets, confirmatory testing for any contaminants or microbiological evidence on passenger blood may be done since no procedures for disinfection were completed and no samples could be taken from any of the passenger.
Bangladesh initially announced the implementation of a lock down for ten days in order to be enforced. Nearly a thousand service holders and factories were already being transported (usually from villages such as Gazipur and Narayanganj) prior to the time of the initial lock down, and some decided to travel long distances, despite the threat of the H3N2 bird flu outbreak, i.e., from Dhaka. The general evacuation and dispersal later, the government made an order for citizens to return to their dwellings within 500 miles of the lower 48 states, and these people began to return home to their original homes from outside of the 48 states (Anwar et al., 2020). Or, when almost all, including the small business owners, felt the economic impact would be too great to be avoided, the government granted an exception and agreed to a somewhat low rate of recovery to allow them to stay open (Zahid, 2020, May 10).

Dhaka has a large population at some periods of the year, but at other times, Eid-Ul-Fitr is an important for expatriates who are emigrants as well, since there is far less pressure on their countries' hospitality at this time. Government agencies, in not having been able to establish proper cooperation among authorities and departments, has allowed illegal activities to expand because of its delay in enforcement of controls(Anwar et al., 2020). Use of caps, gowns, plastic coveralls, and shoe covers to acquire private security equipment and regular respirators was fraud on the part of a section of the ministry of health(Ullah, 2020, April 18 ), notable, who was among the 40,000 health care professionals being charged with selling counterfeit COVID-19 credentials, with more than 1,400 of those people found to be involved in criminal activity (Sumon, 2020, July 11).

\section{Results and Discussion}

As a result of the epidemic's consequences, the existing global economy is on the verge of collapse. Manufacturing chains, buyer demand, and employee well-being all suffer as a result of disease. The loanto-value ratio in Bangladeshi banks is $6 \%$, and the deposit interest rate is $9 \%$. It denotes a reduction in credit demand. The loan volume has been restored to its previous level. Many start-ups that received funding from foreign investors took advantage of the situation. A small-business expansion plan is expected to be released by the administration. COVID-19 is a disease that Bangladesh, like the 
rest of the world, is fighting. Suspension of all public venues and transit services are among the other measures. Improving Bangladesh's entire health- care system, on the other hand, poses a number of challenges. Illegal operations have increased as a result of the sluggish application of rules.

Table 3: The financial incentives announced by the Prime Minister of Bangladesh to tackle the socio-economic losses caused by the lethal COVID-19

\section{Package No. Key Information}

Package $1 \quad$ i) An arrangement of USD 3,529 million was made available to provide working capital to industry and service sector organizations that will serve these sectors and organizations for a short term before new capital is secured.

ii) On the banks' clients' needs, commercial banks can offer a working capital loan of that's not directly tied to equity capital to each to the various sectors and companies in which they operate. Loan interest would be $9 \%$ That is done so that the interest on one half of the debt is borne by the creditor, and the remainder by the government.

Package $2 \quad$ i) Small (cottage) and medium-sized enterprises have profitable working capital: To provide work capital via the banking sector in the short term, a lending facility of approximately USD 2.353 million will be established.

ii) Commercial banks will lend operating resources to the small and medium-sized businesses concerned with their own assets on the basis of banking-client ties. This loan would also have an interest rate of $9 \%$. Small and medium-sized businesses will pay $4 \%$ of loans and the government will pay the remaining $5 \%$ of the loans to the bank in question.

Package $3 \quad$ i) Bangladesh Bank has launched the expansion of the Export Development Fund (EDF) benefits: The scale of the new EDF under the Block to Block LC would rise to \$5 billion from $\$ 3.5$ billion in raw material imports.

ii) This would contribute an extra $\$ 1.5$ million to the EDF fund, equal to $\$ 1.5$ billion. The EDF interest rate would decreases from $+1.5 \%$ (actually $2.73 \%$ ) to $2 \%$ of LIBOR (The London Interbank Offered Rate).

Package 4 The latest loan facility called Pre-Shipment Credit Refinance will be launched by the Bangladesh Bank for approximately USD 589 million. This loan would have an interest rate of $7 \%$.

Package 5 A package of around USD 589 million for emergency incentives for wages and For Agriculallowances for employers and staff in export-focussed sectors has also been declared by Prime Minister.

i) The Bangladesh government has announced that it is providing farmers in rural areas with a new stimulus package of some USD 589 million to improve agricultural output faced with COVID-19 effect. In order to ensure that the non-crop agriculture sub field, which is based on working capital, including seasonal crops of fruit and flower, fisheries, ovine, dairy and livestock, flows in smooth ways. This 'Special Incentive Re-Financing Scheme' is to be provided.

ii) In order to address the country's need for food, various measures were allocated to improve crop development in the middle of the COVID-19 epidemic, including stimulus packages and roughly USD 1060,000.

iii) Around USD 15 million has been earmarked for recovery of farmers, around USD 6 million has been earmarked for natural disaster farmers and for agriculture cooperatives and roughly USD 9 million has been earmarked for expansion of new crops and agricultural techniques.

iv) Approximately USD 23.5 million has been provided for the distribution of machinery and seeds to farmers for agricultural support. The purchasing expenditure of Aus plant 
seeds and fertilizers is approximately US\$ 4,1 million, while irrigation amounts to approximately $\$ 4,25$ million.

v) In an emergency way, 180 combined harvesters and 137 reapers were distributed to farmers of the haor areas to alleviate the possibility of the lack of workers during the harvest season during the period of the COVID-19 epidemic.

vi) Additional US $\$ 12$ million has been dedicated to mechanizing the agriculture sector by the government.

vii) Farmers will soon disperse almost 800 combined harvester harvesters and 400 reapers of this number.

Package $5 \quad$ i) The government has declared a special honorarium program of some USD 12 million

For the for physicians, nurses and the health care sector.

Doctors,

ii) Around USD 88.25,000,000 in health and life insurance coverage.

Nurses and

Health Workers

Package 5 The government has proposed a stimulus plan of around US\$236 million to create jobs For Non- $\quad$ for non-resident Bangladeshi citizens through multiple banks.

Resident

Bangladeshis

Package 5 i. Approximately USD 294.5 million for free delivery to the citizens in need of foodstuffs.

For Social ii. Approximately USD 29.5 million for the 'Rice for TK. 10 per KG' rice sale program

Safety iii. Cash distribution to target populations of about US\$148 million.

iv. For extending the program coverage by approximately USD 96 million.

v. For constructing housing for homeless people approximately USD 250, 6 million.

Source: Islam, M. T., Talukder, A. K., Siddiqui, M. N., \& Islam, T. (2020).

\section{Necessary Recommendations for Path Ahead}

The testing levels in Bangladesh is poor, which means that it will take a long time to rise to the level of the disease curve, since there are a significant numbers of cases with ages above one hundred. as in these conditions, authors suggest implementing proactive initiatives such as expanding the database of Resolute as a way to resist the COVID-19 growth expand on (1) keep the suspect population covered, which are in other levels, namely those that are under age 60, disabled, and undergoing significant medical procedures; (2) investigate the organizational accessibility including nursing homes, clothing, businesses, and industries; (3) in case there may be risk stratification, that is, and older individuals with high-immunesposed patients and defined attentionpaid; (4) check out individuals, which includes people undergoing significant medical procedures, with intact immune systems and particularly the vulnerable populations, who get older, that have different medical treatments. the procedure includes lockdown only if it exceeds defined limits;
(5) collaborator steps including shutting down the facility must be limited according to danger zone; both tertiary-level health facilities need to provide COVID-19-focused care (outpatient and in both public and private settings).

\section{Conclusion}

Today, fearful economic times call for more responsible and proactive leadership in the healthcare sector as well as governments and the broader community demand be prepared for all possible scenarios. Troublesome efforts should be provided until now, such as extra nourishment, smaller ration packs, and a tighter supply, and then expanded as required. After this crisis, the government must address medium and long-term issues to return the economy to equilibrium and also encourage development. In addition, a large socioeconomic development plans that promote micro-businesses and protect ecologically sensitive models should be included in order for more efficient and eco-friendly business-based models to thrive. It 
Vol. 03(1-2) 92-102 (2021)

is wise that governments and financial organizations stay on their toes and consistently meet and keep their promises (Islam, 2020, March 11). Bangladesh, as a lower-middle-income country, has numerous limitations in restricting the spread of the virus, so far preparedness is the key to addressing any health crisis. The country has to expand its testing and healthcare facilities while continuing the lockdown at any cost with stricter maintenance.

\section{Acknowledgement}

I would like to thank all of my co-author for their significant contribution to the research.

\section{Funding}

This research received no specific grant from any funding agency in the public, commercial, or notforprofit sectors.

\section{Conflict of Interest}

There is no conflict of interest

\section{References}

1. Amit, S. (2020). Coronavirus and Impact on the Bangladesh Economy: Assessing the Damage of the Black Swan of 2020. The Asia-Pacific Journal- Japan Focus 18 (15 ). https://apjjf. org/2020/15/Amit.html

2. Anner, M. (2020). Abandoned? The impact of Covid-19 on workers and businesses at the bottom of global garment supply chains. Penn State Center for Global Workers' Rights (CGWR), 29. https://www.workersrights.org/ wp-content/uploads/2020/03/Abandoned-PennState-WRC-Report-March-27-2020.pdf

3. Anwar, S., Nasrullah, M., \& Hosen, M. J. (2020). COVID-19 and Bangladesh: Challenges and How to Address Them [Policy Brief]. Frontiers in Public Health, 8(154). https://doi.org/10.3389/ fpubh.2020.00154

4. Bain, M. (2020, March 21). Coronavirus threatens the livelihoods of garment workers around the world. QUARTZ. https:// qz.com/1821511/coronavirus-threatens-jobsof-garment-workers-in-southeast-asia/

5. Deb, S., \& Nafi, S. (2020). Impact of COVID-19 Pandemic on Tourism: Perceptions from Bangladesh. SSRN Electronic Journal. https:// doi.org/10.2139/ssrn.3632798

6. Desk, T. (2020, April 13). BB issues guideline for Tk $5000 \mathrm{cr}$ stimulus package for agriculture. Dhaka Tribune. https://www.dhakatribune. com/business/banks/2020/04/13/bb-issuesguideline-over-tk5000cr-stimulus-for-agriculture

7. Hasan, B., Sultana, M., \& Hasan, M. N. (2017). Good governance in Bangladesh: Problems and prospects. University of Information Technology \& Sciences (UITS) Journal, 3(2), 22-44.

8. Hasan, M. (2021, Jan 25). Private sector credit growth still depressed. Dhaka Tribune. https://www.dhakatribune.com/ business/2021/01/25/private-sector-creditgrowth-still-depressed\#: :text=It\%20edged\%20 up $\% 2016 \% 20$ basis, $21 \% 20$ is $\% 2014.8 \% 20$ per\%20cent.

9. Hussain, A., Shahzad, A., Hassan, R., \& Doski, S. (2021). COVID-19 Impact on B2B E-Commerce: A Multi- Group Analysis of Sports and Surgical SME's. Pakistan Journal of Commerce and Social Science, 15, 166-195.

10. Islam, M., Talukder, A., Siddiqui, M., \& Islam, T. (2020). Tackling the COVID-19 pandemic: The Bangladesh perspective. Journal of Public Health Research, 9(4), 1794. https://doi. org/10.4081/jphr.2020.1794

11. Islam, S. ( 2020, March 11). BB buys US dollar from banks to keep forex market stable. The Financial Express. https://thefinancialexpress. com.bd/economy/bangladesh/bb-buys-usdollar-from-banks-to-keep-forex-marketstable-1583813208

12. Kamol, E. (2020, Mar 09). Mujib birth centenary inauguration to be on small scale. NEWAGE Bangladesh. https://www.newagebd. net/article/101645/mujib-birth-centenaryinauguration-to-be-on-small-scale

13. Kamruzzaman, M., \& Sakib, S. (2020, March 26). Bangladesh imposes total lockdown over COVID-19. Anadolu Agency. https://www. 
aa.com.tr/en/asia-pacific/bangladesh-imposestotal-lockdown-over-covid-19/1778272

14. McKeever, V. (2020, March 19). Nearly 25 Million Jobs Could Be Lost Globally due to the Coronavirus, UN Labor Organization Estimates. CNBC. https://www.cnbc.com/2020/03/19/ nearly-25-million-jobs-could-be-lost-globallydue-to-the-coronavirus.html

15. Mina, F. B., Billah, M., Rahman, M. S., Das, S., Karmakar, S., Faruk, M., \& Hasan, U. K. A. (2020). COVID-19: transmission, diagnosis, policy intervention, and potential broader perspective on the rapidly evolving situation in Bangladesh. J Adv Biotechnol Exp Ther, 3(4), 18-29.

16. News, I. (2020, June 12). Helping Bangladesh Recover from COVID-19. International Monetary Fund. https://www.imf.org/en/News/ Articles/2020/06/11/na-06122020-helpingbangladesh-recover-from-covid-19

17. Noyon, A. (2020, May 13). A virus that even eats into pharma sector. TBS News. https://www. tbsnews.net/economy/industry/virus-even-eatspharma-sector-80668

18. Onyema, E. M., Eucheria, N. C., Obafemi, F. A., Sen, S., Atonye, F. G., Sharma, A., \& Alsayed, A. O. (2020). Impact of Coronavirus pandemic on education. Journal of Education and Practice, 11(13), 108-121.

19. Perera, W. (2020, March 16). Bangladesh government downplays COVID-19 threat as job losses mount. World Socialist Web Site. https://www.wsws.org/en/articles/2020/03/16/ bang-m16.html
20. Rahman, S., \& Ishty, S. I. (2020, June 24). COVID-19 and the ready-made garment sector. Asia \& The Pacific Policy Society. https://www. policyforum.net/covid-19-and-the-ready-madegarment-sector/

21. Report, S. O. (2020, Sep 6). Mutation of coronavirus in Bangladesh faster than global rate: BCSIR study. The Daily Star. https://www. thedailystar.net/coronavirus-deadly-new-threat/ news/mutation-coronavirus-bangladesh-fasterglobal-rate-bcsir-study-1956841

22. Sumon, S. ( 2020 , July 11). Health workers in Bangladesh charged with selling fake COVID-19 certificates. Arab News. https://www. arabnews.com/node/1702946/world

23. Teti, M., Schatz, E., \& Liebenberg, L. (2020). Methods in the Time of COVID-19: The Vital Role of Qualitative Inquiries. International Journal of Qualitative Methods, 19, 1-5. https:// doi.org/10.1177/1609406920920962

24. Ullah, S. (2020, April 18 ). Healthcare workers in Chattogram dissatisfied over low-quality PPE. The Business Standard. https://www.tbsnews. net/coronavirus-chronicle/covid-19-bangladesh/ healthcare-workers-chattogram-dissatisfiedover-low

25. Worldometer. (2021, August 18). Covid-19 coronavirus pandemic. Worldometer. https:// www.worldometers.info/coronavirus/

26. Zahid, S. H. (2020, May 10). Problems of falling sick. The Financial Express. https:// thefinancialexpress.com.bd/views/problemsof-falling-sick-1589127469 